\title{
Función pacificadora y judicial de los corregidores en las villas y ciudades castellanas, a fines de la edad media
}

María Asenjo-González

\section{(2) OpenEdition Journals}

Edición electrónica

URL: https://journals.openedition.org/medievalista/1075

DOI: 10.4000/medievalista.1075

ISSN: 1646-740X

Editor

Instituto de Estudos Medievais - FCSH-UNL

Referencia electrónica

María Asenjo-González, «Función pacificadora y judicial de los corregidores en las villas y ciudades castellanas, a fines de la edad media», Medievalista [En línea], 18 | 2015, Publicado el 01 junio 2015, consultado el 21 septiembre 2021. URL: http://journals.openedition.org/medievalista/1075; DOI: https://doi.org/10.4000/medievalista.1075

\section{(c) (7) (5)}

Mediavalista está licenciado com uma Licença Creative Commons - Atribuição-NãoComercial 4.0 Internacional. 
Titulo: Función pacificadora y judicial de los corregidores en las villas y ciudades castellanas, a fines de la edad media

Autor(es): María Asenjo-González

Universidade: Universidad Complutense de Madrid

Faculdade e Departamento / Unidade de Investigação: Faculdad de Greografía y Historia Código Postal: 28040

Cidade: Madrid

País:Espanha

Contacto: majonsa@ghis.ucm.es

Fonte: Medievalista [Em linha]. Dir. José Mattoso. Lisboa: IEM.

Disponível em:

http://www2.fcsh.unl.pt/iem/medievalista/MEDIEVALISTA18/gonzalez1804.html ISSN: 1646-740X

Data recepção do artigo: 15 de Março de 2015

Data aceitação do artigo: 22 de Maio de 2015

\section{Resumo}

Desde mediados del siglo XIV y antes de 1480, sabemos que el corregiidor castellano, a instancia de parte, interviene con mayor frecuencia en los concejos. En el presente trabajo pretendemos destacar la mediación pacificadora de los corregidores en las ciudades y la utilidad de su intervención judicial en la conflictiva sociedad urbana bajomedieval, según planteamientos que se alejan del tradicional enfoque institucional. En su cometido, el corregidor aportaría la mediación de su condición social y de prestigio, y actuaría como elemento ajeno a la ciudad, a sus divisiones y conflictos, y provisto de competencias judiciales y punitivas. El éxito de su intervención permitiría que, tras su gestión, la ciudad retomase sus competencias jurisdiccionales, evitando que la conflictividad creciente derivara en una salida de realengo hacia la señorialización. 
Pero el éxito de sus intervenciones y la permanencia del oficio se relacionan también con la creciente convicción social urbana de la necesidad de lograr amparo en una justicia desligada de los poderes locales y de acabar con conflictos que amenazasen la paz cotidiana. Por lo tanto, antes de 1480, los corregidores también habrían contribuido al afianzamiento del realengo y a reavivar el compromiso social de defensa de la justicia y paz en el reino, argumentos señeros del poder monárquico a fines de la edad media.

Palavras-chave: Ciudades, Castilla, Justicia. Gobierno, Corregidores, Instituciones, Historiografía, Sociedad, Política.

\section{Abstract}

From the middle of the fourteenth century, prior to 1480, we know that the Castilian corregidor intervened frequently in councils when his presence was requested. In this paper, using approaches that diverge from the traditional institutional one, I intend to focus on the peace-making mediation of the corregidores in the cities and the usefulness of the part they played in the troubled society of the late Middle Ages. In his task, the corregidor would contribute the mediation of his social rank and prestige and he would act as a neutral element - unconnected with the city, its divisions and its disputes invested with judicial and punitive powers. At the end of his intervention, the success of his actions would enable the city to regain its jurisdictional powers, preventing the growing tensions and disputes that would have justified the change from royal to seigniorial jurisdiction, in some cases. But the success of his actions and the permanence of the office were also associated with the growing urban social conviction of the need to obtain protection in a system of justice that was detached from the local authorities and to put an end to conflicts threatening the everyday peace. Therefore it is my view that, before 1480, the corregidores contributed to the consolidation of royal jurisdiction and to reviving the social commitment to defend justice and peace in the kingdom, the chief arguments of royal power in the late Middle Ages.

Keywords: Cities, Castile, Justice, Government, Corregidores, Institutions, Historiography, Society, Politics. 


\title{
Función pacificadora y judicial de los corregidores en las villas y ciudades castellanas, a fines de la edad media*
}

\author{
María Asenjo-González
}

La presencia del corregidor en las ciudades y villas castellanas, en su función de enviado regio, se documenta desde la primera mitad del siglo XIV, si bien antes de 1480 sabemos que interviene a instancia de parte. Esas primeras actuaciones acabarían en la generalización del envío de corregidores a villas y ciudades que, sin cambiar el propósito de los objetivos que interesaban a la monarquía, fueron asumiendo competencias de vigilancia y preservación del cumplimiento de la justicia. El reconocimiento de las competencias jurisdiccionales a las ciudades castellanas hacía que el recurrir a la intervención del corregidor sólo se contemplara en situaciones de excepción y que él acudiera sólo en calidad de mediador o pacificador, ante la incapacidad o la incompetencia de las justicias y poderes locales, sumidos en diferencias y conflictos.

Por ello, en el presente trabajo trataremos de abordar la figura del corregidor desde la perspectiva de su función y utilidad en las villas y ciudades del reino, justificar las razones de su presencia y reconocer la aportación de su mediación en el contexto político urbano. De ese modo, lejos de entender su figura como resultado de la intervención regia y de la aplicación de sus atribuciones de poder, la llegada del corregidor requerirá de una explicación de su presencia, en el contexto urbano, que justifique no sólo el envío y las atribuciones exhibidas sino las causas de política urbana que requerían su mediación. En ese sentido, por mucho énfasis que se hubiese puesto en 
Función pacificadora y judicial de los corregidores en las villas y ciudades castellanas,

a fines de la edad media María Asenjo-González

conectar la presencia del corregidor en las ciudades con la autoridad regia, lo cierto es que no se ha destacado suficientemente la necesidad de su intervención mediadora, que situara en el marco urbano las razones de su existencia y creciente protagonismo. El desigual reconocimiento y la supuesta política generalizadora muestran las dificultades de implantación, porque ciertamente no se trató de algo impuesto sino de una salida opcional buscada por las ciudades para resolver sus conflictos internos. A pesar de todo se ha considerado que "la reiterada petición de que sólo sean enviados a petición de las ciudades no pasa de ser una mera cláusula de estilo respetada en ocasiones”1.

Las capacidades con las que actuaban los corregidores les permitían gestionar los recursos de la ciudad, hacer frente a las necesidades de avituallamiento de sus habitantes y ejecutar órdenes y mandamientos reales sobre diferentes asuntos, tales como la detención de delincuentes o la publicación de informaciones. Así, por medio de su labor, la Corona intervenía en el gobierno urbano, frenando las aspiraciones hegemónicas de la aristocracia local y enmendando las consecuencias de la rivalidad de poderes con intereses contrapuestos, en un mismo espacio ${ }^{2}$.

Su acción se desarrolló pronto en las ciudades castellanas bajomedievales, que por entonces eran sociedades políticas "descentralizadas" o "corporadas", en las que la gestión del poder estaba fragmentada en un continuum, que no conocía cesura alguna entre la esfera de lo privado y la esfera de lo público ${ }^{3}$. Se comprende, por tanto, que el

\footnotetext{
* Este trabajo se ha realizado en el marco del proyecto HAR2013-44014-P, financiado por el Ministerio de Economía y Competitividad y dirigido por la autora desde la Universidad Complutense de Madrid.

${ }^{1}$ Ver: BERMUDEZ AZNAR, Agustín - El corregidor en Castilla en la Baja Edad Media (1348-1474). Murcia: Universidad de Murcia, 1971, p. 40.

${ }^{2}$ Una visión de conjunto sobre el gobierno de las ciudades en las coronas de Castilla y de Aragón en CERDÁ RUIZ-FUNES, Joaquin - "Jurados, iurats, en municipios españoles de la Baja Edad Media (reflexiones para una comparación)”. in Historia, Instituciones, Documentos. 14 (1987), pp. 27-39. Sobre el caso castellano podemos destacar varios estudios clásicos como los de GONZÁLEZ ALONSO, Benjamin - El corregidor castellano (1348-1808). Madrid: Instituto de Estudios Administrativos, 1970; y BERMÚDEZ AZNAR, Agustín - El corregidor en Castilla durante la Baja Edad Media (1348-1474). Murcia: Universidad de Murcia, 1971, cuyo contenido lo sintetiza en IDEM - "El asistente real en los concejos castellanos medievales”, en VV.AA. - Actas del II Symposium de Historia de la Administración. Madrid, 1971, pp. 223-251; no hemos podido consultar, en cambio, el estudio de GUGLIELMI, Nilda "Los alcaldes reales en los concejos castellanos". in Anales de Historia Antigua y Medieval. 7 (1956), pp. 79-109. También destaca la monografía de ALBI, Fernando - El corregidor en el municipio español bajo la Monarquía absoluta. Madrid: Instituto de Estudios de Administración Local, 1943.

${ }^{3}$ IRADIEL MURUGARREN, Paulino - "Señoríos jurisdiccionales y poderes públicos a finales de la Edad Media”. in Poderes públicos en la Europa Medieval: Principados, Reinos y Coronas. Actas de la
}

Medievalista online № 18| Julho - Dezembro 2015 ๑ IEM - Instituto de Estudos Medievais 4 www2.fcsh.unl.pt/iem/medievalista 
Función pacificadora y judicial de los corregidores en las villas y ciudades castellanas,

a fines de la edad media María Asenjo-González

distanciamiento social y político exigido a los corregidores no fuese fácil. Así, era frecuente encontrar prohibiciones regias a los corregidores para que no viviesen con los regidores ni con otras personas influyentes o que tuviesen voto en el cabildo ${ }^{4}$.

Ahora bien, durante el reinado de los Reyes Católicos el corregidor deja de ser una figura excepcional para convertirse en representante de los intereses reales en los concejos $^{5}$. En ese sentido, las Cortes de 1480 dieron el giro radical al enfoque de la figura del corregidor medieval hacia lo que sería la figura del corregidor castellano moderno, porque acordaron contar con su presencia en las ciudades para ocuparles en la vigilancia y la seguridad junto a otras competencias y asuntos que interesaban a los reyes como la fiscalidad o la defensa ${ }^{6}$. De ese modo, cabe considerar que la generalización de su presencia se inserta en el gran programa político pactado y sancionado por las cortes de Toledo, que ciertamente tuvieron un carácter constituyente para la gobernación del reino, tras el final de la guerra civil en $1476^{7}$. A partir de ese acuerdo, la presencia generalizada del corregidor se fue realizando sin premura, esperando a encontrar la oportunidad que justificase la medida para luego mantener su presencia en el lugar 8 .

XXIII Semana de Estudios Medievales de Estella (22-26 julio 1996). Pamplona: Gobierno de Navarra, 1997, pp. 69-116.

${ }^{4}$ RUIZ POVEDANO, José María - "Poder, oligarquía y parcialidades en Alcalá la Real: el asesinato del corregidor Bartolomé de Santa Cruz". in Historia, Instituciones, Documentos. 29 (2002), pp. 397-427, p. 414.

${ }^{5}$ VAL VALDIVIESO, Isabel - "La intervención real en las ciudades castellanas bajomedievales". in Miscelanea Medieval Murciana. XIX y XX (1995-96), pp. 67-78, p. 73.

${ }^{6}$ Cortes de los antiguos reinos de Castilla y León. vol. 4. Madrid: Real Academia de la Historia, 1882, pp. 57, 65 y ss, 136,140 y ss.

Desde esta perspectiva han sido estudiadas por CARRETERO ZAMORA, Juan Manuel - Cortes, monarquía, ciudades. Las Cortes de Castilla a comienzos de la época moderna (1475-1515). Madrid: Siglo XXI de España, 1998, p. 150. Pero GUERRERO NAVARRETE, Yolanda - "Orden público y corregidor en Burgos (siglo XV)". in Anales de la Universidad de Alicante.Historia Medieval. 13, 20002002, p. 6, opina con acierto que tal medida no pudo aplicarse sin la complicidad de las sociedades urbanas implicadas

${ }^{8}$ Cuando el corregidor Bartolomé de Santa Cruz llegó a Alcalá la Real en 1489 la institución era inédita y muy novedosa en la localidad: RUIZ POVEDANO, José María - "Poder, oligarquía y parcialidades en Alcalá la Real: el asesinato del corregidor Bartolomé de Santa Cruz”. in Historia, Instituciones, Documentos. 29 (2002), pp. 397-427, p. 410.

Medievalista online № 18| Julho - Dezembro 2015 @ IEM - Instituto de Estudos Medievais 5 www2.fcsh.unl.pt/iem/medievalista 
Función pacificadora y judicial de los corregidores en las villas y ciudades castellanas,

a fines de la edad media María Asenjo-González

\section{El estudio de la figura del corregidor}

El corregidor castellano cuenta con un interesante conjunto de trabajos para la época medieval y moderna ${ }^{9}$, y, siguiendo los enfoques predominantes, la bibliografía podría quedar agrupada en tres apartados:

1) Los trabajos de enfoque institucionalista, que han sido los que han insistido más sobre la idea de que, en las ciudades, surge la figura del corregidor para solucionar las problemáticas derivadas de la instauración del regimiento, entienden que se trata de un oficial y una autoridad de nombramiento y elección regia que, además de gobernar, imparte justicia en nombre del rey ${ }^{10}$. Así, la institución del corregimiento aparecería plenamente justificada en el contexto de la aparición del regimiento, y conectada a las medidas encaminadas a la centralización del poder monárquico sobre las ciudades. Esa percepción del oficio de los corregidores como "delegados reales", conectada al autoritarismo monárquico, aparecería en ciernes en el reinado de los primeros Trastámaras, y se afianzaría en el reinado de los Reyes Católicos. Pero este enfoque necesariamente se justificaba en un contexto de decadencia de la autonomía concejil del primer concilium, en el período bajomedieval, destacado por los institucionalistas ${ }^{11}$. Un proceder que conectaría también con la recepción del derecho romano, ius comune, a partir del siglo XIII, y se serviría de determinados pretextos de conflictividad, como el choque entre linajes urbanos, para justificar la presencia del polémico enviado regio. El modelo institucionalista se ocupaba, en sus análisis, de los mecanismos y métodos de

\footnotetext{
${ }^{9}$ Algunos títulos pueden ser significativos: ALBI, Fernando - El corregidor en el municipio español bajo la monarquía absoluta. Madrid: Instituto de Estudios de Administración Local, 1943; GONZÁLEZ ALONSO, Benjamin - El corregidor castellano (1348-1808). Madrid, Instituto de Estudios Administrativos, 1970; BERMUDEZ AZNAR, Agustín - El corregidor en Castilla en la Baja Edad Media (1348-1474). Murcia: Universidad de Murcia, 1971; BONACHIA HERNANDO, Juan Antonio “Materiales para el estudio del régimen de corregidores (Burgos 1458-1465)". in Cuadernos de Historia de España. 75 (1998-1999), pp. 135-159; LUNENFELD, Marvin - Los corregidores de Isabel la Católica. Barcelona: Labor, 1989; MITRE FERNÁNDEZ, Emilio - La extensión del régimen de corregidores en el reinado de Enrique III de Castilla. Valladolid: Universidad de Valladolid, 1969; RUFO YSERN, Paulina - "Extensión del régimen de corregidores en Andalucía en los primeros años del reinado de los Reyes Católicos”. in LOPEZ DE COCA CASTAÑER, José Enrique; GALÁN SÁNCHEZ, Angel (ed.) - Las ciudades andaluzas (siglos XIII-XVI). Actas del VI Coloquio Internacional de Historia Medieval de Andalucía. Málaga: Universidad de Málaga, 1991, pp. 55-75.

${ }^{10}$ FONT RIUS, José María - Instituciones medievales españolas. Madrid: CSIC, 1949, pp. 44-48 y GARCIA DE VALDEAVELLANO, Luis - Curso de Historia de las Instituciones españolas. De los orígenes al final de la Edad Media. Madrid: Revista de Occidente, 1968, pp. 550-551.

${ }^{11}$ MITRE FERNÁNDEZ, Emilio - La extensión del régimen de corregidores..., op. cit., pp. 16-17.
}

Medievalista online № 18| Julho - Dezembro 2015 ๑ IEM - Instituto de Estudos Medievais 6 www2.fcsh.unl.pt/iem/medievalista 
acción del corregimiento, vinculándolo a las instituciones regias y considerando su presencia e intervención como emanación de las atribuciones de un poder regio creciente y decidido a extender su dominio al ámbito municipal.

2) Desde un enfoque más político, centrado en la conflictividad social, otros autores se preguntan por la naturaleza de su poder y de sus medios de acción ${ }^{12}$. Así, I. del Val asegura que el corregidor sería parte de la estrategia de enfrentamiento dialéctico entre el “centralismo regio y “la autonomía local”, ya que la centralización manifestada por el "Estado" hacía posible el intervencionismo regio que, a pesar de que encontrará resistencia en las ciudades, lograría imponer la tendencia que favorecía a la dominación de la oligarquía urbana ${ }^{13}$. Ese enfoque de participación regia, que favorece a las élites con el envío del corregidor a la ciudad, se centraría en destacar la existencia de una resistencia urbana instalada entre el poder del Estado, la Corona, y la oligarquía urbana $^{14}$. Lo cual hace ajena a la oligarquía local de la realidad social urbana en la que arraiga y se justifica, y la presenta como una anomalía, tanto desde un punto de vista político como social. Además, esa percepción hace de la figura del corregidor un mero instrumento al servicio del poder centralizador, que frecuentemente actuaba en connivencia con los miembros de la oligarquía urbana y contra los intereses de la población urbana. Esa misma idea de creciente autoritarismo regio, en la que el monarca impone al corregidor, se sitúan los argumentos de los estudios sobre el Estado moderno de los años ochenta y noventa, que aseguraban que su figura respaldaba a la minoría que beneficia a sus intereses ${ }^{15}$.

${ }^{12}$ VAL VALDIVIESO, Isabel - "La intervención real en las ciudades castellanas bajomedievales". in Miscelánea Medieval Murciana. 19-20 (1995), pp. 67-78.

${ }^{13}$ La figura del corregidor respalda a la minoría que beneficia sus intereses y favorece la colaboración entre los agentes del Estado y la clase dominante urbana "que beneficia a ambos y garantiza el sometimiento a su poder del resto de los habitantes de la ciudad" (Ibidem, p. 69).

${ }^{14}$ GUERRERO NAVARRETE, Yolanda - "Orden público y corregidor en Burgos (siglo XV)". in Anales de la Universidad de Alicante. Historia medieval. 13 (2000), pp. 59-102, p. 95.

${ }^{15}$ CASADO ALONSO, Hilario - "Las relaciones poder real - ciudades en Castilla en la primera mitad del siglo XIV”. in RUCQUOI, Adeline (ed.) - Génesis medieval del Estado Moderno - Castilla y Navarra (1250-1370). Valladolid : Ámbito, 1987, pp. 193-215 ; MENJOT, Denis - "La ville et l'Etat moderne naissant: la monarchie et le Concejo de Murcie dans la Castille des Trastamares d'Henri II à Henri IV”. in RUCQUOI, Adeline (ed.) - Realidad e imágenes del poder. España a fines de la Edad Media. Valladolid: Ámbito, 1988, pp. 115-135. 
3) Desde un análisis menos definido, aunque partícipe del modelo institucionalista y reconocedor de una conflictividad social detonadora, algunos estudios se ocuparon de la actitud de los corregidores, su pertinencia y capacidad para resolver los conflictos o destacaron su participación interesada al integrarse en ellos. Probando así como la institución no funcionó de manera oficial y uniforme, en todas las ciudades, ya que algunos corregidores actuaron de forma partidista cuando intervinieron en las luchas de facciones ${ }^{16}$.

Cabe observar también como, los trabajos de los últimos decenios, la figura del corregidor ha reconducido tanto su papel como su capacidad de acción, en calidad de enviado regio, también en el marco de una monarquía autoritaria, para presentarle como un mediador coyuntural necesario, dotado de competencias jurídicas fragmentadas y sujetas a los vaivenes de las alianzas y rivalidades políticas de circunstancia ${ }^{17}$. Un enfoque desde el que se entiende mejor que la figura del corregidor hubiese sido asignada inicialmente a personas con prestigio y estatus social, que hicieran valer su posición en situaciones de conflicto, dado el carácter de poder ajeno y mediador de su competencia.

${ }^{16}$ DIAGO HERNANDO, Máximo - "El papel de los corregidores en los conflictos políticos en las ciudades castellanas a comienzos del siglo XVI”. in En la España medieval. 27 (2004), pp. 195-223.

${ }^{17}$ Los estudios se centran en mostrar a los corregidores en la gestión de conflictos en un marco local o desde enfoques sociales y políticos en ese mismo contexto: MONSALVO ANTON, José María "Centralización monárquica castellana y territorios concejiles (Algunas hipótesis a partir de las ciudades medievales de la región castellano-leonesa". in Anales de la Universidad de Alicante. Historia Medieval. 13 (2000-2002), pp. 157-202; PEINADO SANTAELLA, Rafael G. - "Una propiedad latifundista en el reino de Granada: la hacienda del corregidor Andres Calderon (1492-1500)". in Chronica Nova. 22 (1995), pp. 303-355; POLO MARTíN, Regina - "Términos, tierras y alfoces en los municipios castellanos de fines de la Edad Media". in Anuario de Historia del Derecho Español. LXXII, n ${ }^{\circ}$. Enero (2002), pp. 201-304; RUIZ POVEDANO, José María - “Poder, oligarquía y parcialidades...”, op. cit., pp. 397-427; SOLÓRZANO TELECHEA, Jesús Ángel - "Violencia y conflictividad política en el siglo XV: el delito al servicio de la elite en las Cuatro Villas de la Costa de la Mar". in Anuario de Estudios Medievales. 35 (2005), pp. 159-184.

Medievalista online № 18| Julho - Dezembro 2015 ๑ IEM - Instituto de Estudos Medievais 8 www2.fcsh.unl.pt/iem/medievalista 
Función pacificadora y judicial de los corregidores en las villas y ciudades castellanas,

a fines de la edad media María Asenjo-González

\section{Las competencias del corregidor: de emisario regio a juez real}

Los corregidores y asistentes reales se encuentran documentados desde la primera mitad del siglo XIV y existen noticias de sus precedentes, los llamados alcaldes del rey y jueces de salario, contrapuestos a los alcaldes foreros vigentes, en el siglo anterior. Recordemos que jueces y alcaldes, con la ayuda de los jurados, velaban por el cumplimiento de las normativas áulicas y a ellos se les atribuían competencias en asuntos en los que la tarea de la justicia se identificaba con la de gobierno, siempre sobre el argumento de que un buen gobierno era un gobierno justo, unido al bien común. En este sentido, las figuras del juez de salario, el gobernador y el asistente se pueden considerar los precedentes del corregidor, si bien el primero es más un juez, el segundo tiene una naturaleza más militar y el tercero es un interventor en el plano normativo $^{18}$. En esa práctica, fueron las Cortes de 1480 las que dieron el giro hacia la consolidación de la figura del corregidor castellano moderno, en las ciudades y villas del reino, aunque las competencias y la función práctica de los corregidores de los siglos XIV y XV fueron perfilando y definiendo las posibilidades de sus atribuciones futuras ${ }^{19}$.

Su intervención en las tareas judiciales es uno de los asuntos más destacados, si bien cabe reconocer que la justicia requería de las funciones de mediación y la habilidad gestora en las sociedades del pasado ${ }^{20}$. Pero han sido las elaboraciones complejas, conectadas a las competencias del poder regio o a las necesidades del bien común, las que han relegado a un segundo plano la reflexión sobre la función básica de la justicia en las primeras sociedades urbanas, tal y como se recogían en los fueros. Por entonces,

\footnotetext{
${ }^{18}$ BONACHIA HERNANDO, Juan Antonio - "La justicia en los municipios castellanos medievales”. in Edad Media. Revista de Historia Medieval. 1 (1998), pp. 145-182: Trabajo de revisión bibliográfica que plantea seguir el desarrollo de la justicia municipal frente al creciente aumento del poder regio. Este inicia su despegue en el reinado de Alfonso X y se afirma con el Ordenamiento de Alcalá que pospone el derecho foral, p. 156.

19 LUNENFELD, Marvin - Los corregidores de Isabel la Católica. Barcelona: Labor, 1989. CARRETERO ZAMORA, Juan Manuel - Cortes, monarquía, ciudades. Las Cortes de Castilla a comienzos de la época moderna (1475-1515). Madrid: Siglo XXI, 1988, p. 168.

${ }^{20}$ BONACHIA HERNANDO, Juan Antonio - "La justicia en los municipios castellanos medievales". in Edad Media. Revista de Historia Medieval. 1 (1998), pp. 145-182; ALFONSO ANTÓN, María Isabel "Resolución de disputas y prácticas judiciales en el Burgos medieval". in Burgos en la Plena Edad Media. III Jornadas burgalesas de Historia. Monografías de Historia Medieval castellano-leonesa. Burgos: Asociacion Provincial de Libreros de Burgos, 1994, pp. 211-243.
}

Medievalista online № $18 \mid$ Julho - Dezembro 2015 ๑ IEM - Instituto de Estudos Medievais 9 www2.fcsh.unl.pt/iem/medievalista 
la justicia foral era percibida como algo orgánico derivado de acuerdos y aplicación de leyes, y sujeta a los condicionantes de la acción de gobierno. Desde 1348 el panorama legal en Castilla cambia y las leyes y la justicia del rey fueron ganando atribuciones, sin olvidar que justicia y gobierno formaban parte de un binomio indiscutible, en el marco de cualquier situación política y social. Algo que debería de ser tenido en cuenta a la hora de analizar las acciones de los corregidores, en las que pesan más las nociones de enfoque institucional, que atienden a las competencias de poderes superiores arropados de argumentos teóricos y doctrinales, y justifican sus competencias en el ámbito legal más en clave teórica que como consecuencia del estudio de la praxis y de la aplicación de soluciones a los conflictos legales planteados. Una apreciación distinta del ejercicio de la justicia requeriría diferenciar entre poderes de iure y poderes de facto, para comprender el alcance de la justicia en las diferentes épocas y contextos ${ }^{21}$.

Sabemos que, en el caso castellano, la reivindicación de las competencias de justicia iba unida al requerimiento de dominio sobre vasallos y territorio, en el ejercicio de la jurisdicción, que también tenían reconocida los concejos de las ciudades y villas de realengo, en equivalencia a las competencias de los señores laicos y eclesiásticos. Esas atribuciones eran algo más que una afirmación formal de autonomía política de elaborada construcción teórica, ya que conllevaban responsabilidades y capacidades de poder, que permitieron el desarrollo de los señoríos colectivos urbanos como sociedades políticas complejas. La dificultad de asegurar una justicia equitativa y distributiva para todos se percibe en las recomendaciones de la tercera Partida, en las que el rey Alfonso $\mathrm{X}$ alude a nociones teóricas de justicia al afirmar que se asocia a la existencia de juicio y ofrece en apelación la intervención de los tribunales del rey ${ }^{22}$.

Pero fue en el curso del siglo XIV cuando las luchas por el poder, en el seno de la mayoría de los concejos castellanos, introdujeron elementos de debate, que ponían en cuestión las garantías y seguridades legales de aplicación de la justicia, porque esta

\footnotetext{
${ }^{21}$ Una reflexión sobre la aplicación de la justicia en el marco de la ciudad de Florencia en: ZORZI, Andrea - L'amministrazione della giustizia penale nella repubblica Fiorentina. Firenze: Leo S. Olschki Editore, 1988, p.12.

${ }^{22}$ Según Alfonso X: Justicia "Se debe hacer ordenadamente por seso y por sabiduría, y demandando y defendiendo cada uno en juicio lo que cree que sea su derecho, ante los grandes señores e los oficiales que han de juzgar por ellos": Las Siete Partidas. Antología. Madrid: Castaglia, Odres Nuevos, 1992, p. 239 y ss.
}

Medievalista online № 18| Julho - Dezembro 2015 ๑ IEM - Instituto de Estudos Medievais 10 www2.fcsh.unl.pt/iem/medievalista 
Función pacificadora y judicial de los corregidores en las villas y ciudades castellanas,

a fines de la edad media María Asenjo-González

quedaba desautorizada cuando surgían situaciones de desgobierno ${ }^{23}$. En muchas ciudades tales conflictos se asociaron a la aparición del regimiento, en tanto que modelo oligárquico de gobierno, ya que entonces se produjeron situaciones de conflictividad que sirvieron como justificación para la instauración del regimiento o gobierno cerrado en el concejo y también la aceptación del ordenamiento del Alcalá de 1348, con los cambios asociados en la aplicación de la justicia y al refuerzo de la acción regia para la recuperación de la $\mathrm{paz}^{24}$.

Las solicitudes de envío de corregidores no se conservan, aunque se sabe de las mismas de forma indirecta, por alusiones en documentos de emisión regia o por referencias, que dejan constancia de que el corregidor llegaba a instancia de parte. Los reyes atendían la solicitud, designando al corregidor, y resulta interesante que, en las primeras nominaciones, también interviniese el Consejo Real ${ }^{25}$.

En la ciudad de destino, el corregidor actuaba como único juez, suprimiendo a los alcaldes foreros, tanto en las competencias que tuviesen sobre el cometido asignado como en otros litigios ${ }^{26}$. No se sabe con certeza si su presencia anulaba o extinguía completamente las competencias de los alcaldes y oficiales del concejo pero, a juicio de A. Bermúdez Aznar, su intervención se ajustaba al concepto amplio que existía de la justicia en la edad media, por el que llegaba capacitado para intervenir en muchos de los aspectos del acontecer social que se consideraban de competencia de la justicia regia ${ }^{27}$. Por eso cabe pensar que los corregidores verían agrandado su campo de acción respecto

\footnotetext{
${ }^{23}$ La burla de la justicia, la inseguridad ciudadana y los áridos debates en el concejo y en el ayuntamiento de Burgos, dieron pie a denuncias ante los oficiales regios: GUERRERO NAVARRETE, Yolanda “Orden público y corregidor...”, op. cit, p. 39.

${ }^{24}$ La conexión entre la instauración del regimiento y la trasformación en la gestión de la justicia aplicada con el ordenamiento de Alcalá la tratamos en: ASENJO GONZALEZ, María - "La aristocratización política en Castilla y el proceso de participación urbana (1252-1520)”. in NIETO SORIA, José Manuel C. (ed.) - La monarquía como conflicto en la Corona castellano-leonesa (1250-1450). Madrid: Silex, 2006, pp. 133-196, p. 134, aunque ya fue destacada por MINGUEZ FERNANDEZ, José María - "La transformación social de las ciudades y las Cortes de Castilla y León”. in Las Cortes de Castilla y León en la Edad Media: actas de la primera etapa del Congreso científico sobre la historia de las Cortes de Castilla y León, Burgos, 30 de septiembre a 3 de octubre de 1986. 2 vols., Valladolid: Cortes de Castilla y León, 1988, pp. 13-43.

${ }^{25}$ BERMUDEZ AZNAR, Agustín - El corregidor en Castilla..., op. cit., vol 1, p. 87.

${ }^{26}$ Ibidem, p. 62.

${ }^{27}$ Algunos autores como Sacristán consideran que la justicia local quedaba anulada (p. 361.362) y Gibert piensa que los corregidores reasumían las funciones de los alcaldes foreros (“La ciudad castellana”, pp. 12-14: Font Rius y García Gallo también mantienen el desplazamiento de los jueces locales.
}

Medievalista online № 18| Julho - Dezembro 2015 ๑ IEM - Instituto de Estudos Medievais 11 www2.fcsh.unl.pt/iem/medievalista 
al motivo de su nombramiento, ya que castigarían delitos y velarían por el mantenimiento del orden público, además de intervenir en la buena gobernación y evitar los conflictos, las rivalidades y diferencias que se produjeran ${ }^{28}$.

De ese modo, cabe reconocer que si la rivalidad política local anulaba la función de justicia en el concejo, sólo se recuperaría con la llegada del corregidor, que la restablecía y, en cierto modo, aseguraba la funcionalidad de jurisdicción de realengo en la ciudad y su territorio. Ciertamente el éxito pacificador y judicial del corregidor evitaría la entrega del concejo a la jurisdicción señorial, como salida a la violencia política concejil durante el período Trastámara ${ }^{29}$. Por ello se entiende que las ciudades no dudaron en ceder competencias al corregidor, casi en situación extrema, con el propósito de poder reinstaurarlas, tras la pacificación, y asegurar así las formas políticas del poder oligárquico ${ }^{30}$. Pero la intervención de los corregidores a instancia de parte permitió prolongar su presencia en el regimiento, limitando y condicionando el predominio de los regidores y de su gobierno oligárquico. En ese sentido, algunos autores han considerado que la intervención de los corregidores representaría, en cierto modo, la recuperación y salvaguarda de la pureza de la legalidad municipal, respaldada por el rey y despegada del poder de los regidores ${ }^{31}$.

El carácter mediador del cargo y las competencias del corregimiento se ponen de manifiesto en su funcionamiento desde los inicios de la institución. Así se constata que, en tiempos de Enrique III, los cargos eran asignados a miembros de la nobleza y hombres de la confianza del rey, aportando estatus y respeto a su acción, que eran valores incuestionables en una sociedad jerarquizada. Su cometido era poner paz y

\footnotetext{
${ }^{28}$ Ibidem, p. 66.

${ }^{29}$ La entrega de la jurisdicción sobre villas y ciudades de realengo a los señores de la nobleza fue otro modo de contener las rivalidades y conflictos internos. Interpretación que se inserta en el marco de la rivalidad "nobleza-monarquía", que se consideraba que había presidido la etapa Trastámara en Castilla. Se piensa que las ciudades prefieren que las sojuzgaran a la monarquía antes que el sometimiento a la nobleza: Ibid. p. 65. Sobre la cuestión de nobleza-monarquía consultar: SUAREZ FERNANDEZ, Luis Nobleza y monarquía. Puntos de vista sobre la historia castellana del siglo XV. Valladolid: Universidad de Valladolid, 1975.

${ }^{30}$ Las cartas de nombramiento "constaban de un protocolo inicial, una parte expositiva, otra dispositiva y el protocolo final. La primera parte se inicia siempre con la tradicional intitulación, seguida de la dirección, salutación y notificación. La expositiva mencionaba los motivos que habían sido tenidos en cuenta para proceder al nombramiento tales como perturbaciones del orden público, mala administración de justicia, etc.”, BERMUDEZ AZNAR, Agustín - El corregidor en Castilla..., op. cit., vol 1, p. 98.

${ }^{31}$ Ibid., p. 67.
}

Medievalista online № 18| Julho - Dezembro 2015 ๑ IEM - Instituto de Estudos Medievais 12 www2.fcsh.unl.pt/iem/medievalista 
Función pacificadora y judicial de los corregidores en las villas y ciudades castellanas,

a fines de la edad media María Asenjo-González

hacer justicia y fueron las ciudades las que reclamaron su presencia, en los primeros tiempos de este oficio, a donde llegaron casi siempre a petición de parte. Pero, tal y como se ha dicho, la estancia del corregidor y sus alcaldes se aprovechaba para juzgar otros asuntos y diferencias que interesaban a los vecinos y que requerían no sólo de un mediador de estatus y reconocido prestigio sino de aquellos que tuviesen conocimiento en el manejo de las leyes para impartir una justicia modélica ${ }^{32}$.

Juan II envió corregidores para mediar en luchas de poderes en las ciudades, pero sabemos que ellos frecuentemente quedaban atrapados en las divisiones de la contienda por lo que insistentemente se les ordenaba actuar de manera rigurosa y elaborar un informe de los hechos que permitiese encausar a los culpables con la intervención inmediata de los tribunales regios. La situación de desgobierno que reclamaba su presencia queda bien reflejada en la crónica:

\footnotetext{
"Que por quanto en las cibdades é villas de sus Reynos habia muchos vandos, por los quales se siguian muchas muertes de hombres, é robos é quemas é otros grandes maleficios, de lo qual se siguia daño en todos sus Reynos, é por esta causa muchas veces él embiaba sus Corregidores, los mas de los quales usaban de tal manera en los Corregimientos, que dexaban en los lugares mayor division que quando á ellos venian; é que por esto el Rey mandaba que todos los Corregidores que él embiase á qualesquier villas ó lugares de sus Reynos, fuesen tenidos de hacer verdadera relación a Su Merced de quien ó quales personas eran los que revolvian los tales vandos. E habida esta relacion por el Rey, luego los mandase venir á su Corte personalmente, dándoles Jueces que los oyesen, é mandando á su fiscal que los acusase; lo qual así se puso en obra, é se guardó algun tiempo, é fue hecha justicia de algunos, é otros fueron desterrados por ciertos tiempos, segun la culpa en que los hallaron” 33 .
}

\footnotetext{
32 Eso es lo que también vemos expresado ya en los documentos de fines del siglo XIV y principios del XV: MITRE FERNÁNDEZ, Emilio - La extensión del régimen de corregidores..., op. cit., pp. 47 y ss. , ya que los primeros corregidores fueron nobles u hombres buenos con prestigio y proximidad al rey pero de algunos de sus alcaldes se valoró su buen hacer como hombres de leyes. Así en 1406 el concejo de Murcia envía una carta al rey Enrique III, alabando la actuación del alcalde Sancho Ruiz que actuaba como oficial de justicia del corregidor Juan Rodríguez, doc. 9, pp. 88-89

${ }^{33}$ AAVV, Crónicas de los Reyes de Castilla. Tomo II (BAE). Madrid: Ed. Atlas, 1953, p. Crónica del Serenísimo Príncipe don Juan, segundo Rey"..., op. cit., Cap. V, pág. 516; Crónica de Juan II, pp. 516 y ss. La pena de destierro era la más frecuentemente aplicada en estos casos. Ver: ASENJO GONZÁLEZ, María - "La exclusión como castigo. La pena de destierro en las ciudades castellanas a fines del siglo XV”. in Anales de la Universidad de Alicante. Historia Medieval. 18 (2012), pp. 67-97
}

Medievalista online № 18| Julho - Dezembro 2015 ๑ IEM - Instituto de Estudos Medievais 13 www2.fcsh.unl.pt/iem/medievalista 
Para evitar el proceder descarriado del corregidor se dice en la crónica que se le instruía en las precauciones convenientes a las funciones de justicia y por ello se le conminaba a que contase con los colaboradores adecuados y actuase con imparcialidad en el ejercicio de su cargo:

\begin{abstract}
"Ordeno é mando que quando algunos Corregimientos se ovieren a dar en las çibdades e villas e lugares de los mis Reynos, se guarde la forma de la ley sobrello ordenada, é que el Corregidor sea tal qual cumpla al mi servicio é á esecucion de la mi justicia, proveyendo el oficio mas que á la persona, é que jure que no dió ni prometió, ni dará ni prometerá cosa alguna por esta razon, ni dara cosa ni parte de lo que rentare el oficio á persona alguna, so pena de perjuro é de infame, é de haber perdido el oficio á persona alguna, so pena de perjuro é de infame é de haber perdido el oficio, é nunca poder haber otro, é que este juramento haga en la ciudad, ó villa, ó lugar de que lo que yo proveyere de tal Corregimiento por ante Escribano público; é eso mesmo se haga é guarde en las Alcaldías é otros oficios de justicias é Alguacilazgos é Merindades de yo he de proveer" ${ }^{34}$.
\end{abstract}

Se contaba con miembros de la pequeña nobleza y patriciado urbano para el cargo, si bien otra posible procedencia de los corregidores era el oficio de armas y se recurría a militares que tenían responsabilidades como tenentes de fortalezas o eran adelantados de determinadas regiones. A su vez, los corregidores asumían competencias militares allí donde eran nombrados y se solían encargar de la defensa y custodia de las fortalezas y supervisión de los alardes militares en los concejos. También las autoridades militares ejercieron de corregidores en villas de sus demarcaciones geográficas de actuación. Este fue el caso, por ejemplo, de los capitanes generales de la frontera navarra, que no solo presionaron a los corregidores de ciudades como Logroño, para que desarrollaran su actividad del modo que consideraban más apropiado a su interés, sino actuaron como corregidores en varios momentos en los que no había alguno designado expresamente.

Pero no todo eran ventajas para las ciudades porque con en los excesos de violencia y enfrentamientos, la intervención regia, por medio del corregidor, acababa reforzando su poder jurisdiccional supeditando las jurisdicciones existentes a la de la justicia regia y ordenando que todos se sometiesen a ella. Esas medidas contenían por un tiempo la situación de violencia pero que no aseguraban la solución del conflicto. Además, el

${ }^{34}$ Ibidem, p. 531.

Medievalista online № 18| Julho - Dezembro 2015 ๑ IEM - Instituto de Estudos Medievais 14 www2.fcsh.unl.pt/iem/medievalista 
salario del corregidor era elevado (200 mrs. diarios) y el pago del mismo, que recaía en la ciudad, se hacía gravoso y contra su presencia se pronunciaban distintos estamentos de la misma. Generalmente, se pagaba con las rentas fijas, como Segovia lo hacía del arrendamiento de la dehesa de Valsaín, o bien con una sisa en productos de consumo urbano que asegurase la recaudación. En concejos como Alcalá la Real el debate enfrentó a regidores y común, ya que éste pedía que los gastos del salario se pagaran de los propios y los regidores lo ponían en la sisa, que pagaban todos los vecinos en tanto que consumidores ${ }^{35}$.

La ausencia de los corregidores de las ciudades en las que ejercían sus cargos se compensaba con el nombramiento de lugartenientes y oficiales que le supliesen, para así poder atender sus otros oficios e intereses, ya que algunos eran regidores de otras ciudades y tenían haciendas y cometidos en esas regiones. Lo curioso es que los lugartenientes y oficiales, nombrados para suplirles, sí solían ser vecinos de la ciudad, tal y como ocurría en Calahorra, con lo que se comprometía su imparcialidad ${ }^{36}$. Es más, podía suceder que los corregidores fuesen nombrados para actuar en dos o más ciudades y villas a la vez, aunque, por lo general esa compatibilidad se aplicaba entre ciudades de desigual relevancia y rango político, que lo compartían por razones de proximidad. Ese fue el caso de Andújar que lo compartió con Jaén y Huete con Cuenca ${ }^{37}$.

La vida política convulsa que se documenta en la segunda mitad del siglo XIV se puede poner en relación con la reciente repoblación de Andalucía y Murcia, y con la inestable y combativa oligarquía que lo gobernaba. En ellas la presencia del grupo de caballeros estaba justificada por la proximidad de la frontera y los hombres buenos no representaban más que a una parte del sector jerárquico, en pugna por su afianzamiento y estatus social ${ }^{38}$. Además, en Murcia, la figura del Adelantado mayor se convertiría en

${ }^{35}$ RUIZ POVEDANO, José María - “Poder, oligarquía y parcialidades...”, op. cit., p. 415.

${ }^{36}$ DIAGO HERNANDO, Máximo - "El papel de los corregidores en los conflictos políticos en las ciudades castellanas a comienzos del siglo XVI”. in En la España medieval. 27 (2004), pp. 195-223, p. 202.

${ }^{37}$ En 1484, Diego López de Ayala era corregidor de Úbeda y Baeza y Francisco de Bobadilla de Jaén y Andújar: MARTÍNEZ MAZAS, José - Retrato al natural de la ciudad y término de Jaén. Jaén: en la Imprenta de D. Pedro de Doblas, 1794, p. 109.

${ }^{38}$ En cuanto a los precedentes del regimiento, como modelo de gobierno, se encuentran en Andalucía desde el siglo XIII y en Murcia había concejo cerrado en 1325, designando a cuarenta caballeros y hombres buenos para que atendiesen las cosas del concejo, pero hasta 1350 no tuvo 13 regidores, que

Medievalista online № 18| Julho - Dezembro 2015 ๑ IEM - Instituto de Estudos Medievais 15 www2.fcsh.unl.pt/iem/medievalista 
un elemento polarizador de afinidades, que desestabilizaba la política urbana y generaba una dinámica propia de afecciones y discrepancias en la ciudad ${ }^{39}$. En ese contexto político, las intervenciones regias para remediar acciones de mal gobierno se fueron sucediendo hasta que Enrique II envió supuestamente a un corregidor, al que se oponía el concejo en $1398^{40}$.

En Sevilla la mención de intervención regia en relación con la justicia, en tiempos de Enrique III, acaba con el alcalde puesto por el mayordomo para sustituirlo por cinco fieles/alcaldes elegidos dos del grupo de los veinticuatro (regidores), dos de los ciudadanos y uno de los jurados. Al mismo tiempo, se estableció que los dichos fieles requirieran a don Ferrand Dantes, maestre de Santiago de Portugal, a quien nombra asistente y ejecutor de mayo a enero y un año más con un salario de $15.000 \mathrm{mrs}^{41}$.

Pero la conexión entre la presencia de los corregidores en los concejos y el mantenimiento del orden y la paz, en el marco de la instauración del regimiento, ha sido uno de los aspectos destacados por la bibliografía para justificar su difusión, si bien no parece cumplirse en todos los casos, ya que algunas ciudades acceden al regimiento sin grandes alborotos y no lo precisaron ${ }^{42}$. Hay que considerar que, aunque hubiese razones de disidencia y conflicto interno en las ciudades de mediados del siglo XIV, se necesitaban soluciones de paz para regir el concejo y eso pasaba por reducir el número de los asistentes a las reuniones y adecuar esa presencia al nuevo modelo social de creciente predominio oligárquico. Hay que reconocer que el modelo de gobierno del regimiento representaba en si un paso cualitativo hacia una fórmula de construcción oligárquica más acorde a los tiempos y a las transformaciones económicas y sociales de

irían aumentando y reduciendo su número hasta fines del siglo XV: TORRES FONTES, Juan "Evolución del concejo de Murcia en la Edad Media”. in Murgetana. LXXI (1987), pp. 5-47, pp. 22-26.

${ }^{39}$ MENJOT, Denis - "La ville et l'Etat moderne naissant: la monarchie et le Concejo de Murcie dans la Castille des Trastamares d'Henri II à Henri IV”. in RUCQUOI, Adeline (ed.) - Realidad e imágenes del poder. España a fines de la Edad Media. Valladolid: Ambito, 1988, pp. 115-135.

${ }^{40}$ BERMUDEZ AZNAR, Agustín - El corregidor en Castilla ..., op. cit., vol. 2, p. 460. Murcia 13 de enero de 1398. Temor expresado por el concejo ante la llegada del corregidor. Recordemos que fue en Murcia donde aparecieron los títulos de corregidor y justicia mayor referidos a un mismo personaje, con lo que se pone de manifiesto su idéntica función.

${ }^{41}$ MITRE FERNÁNDEZ, Emilio - La extensión del régimen de corregidores..., op. cit., pp 80-81.

${ }^{42}$ Las menciones a corregidores enviados a las villas y ciudades se documentan en el siglo XIV, asociados en muchos casos a la instauración del regimiento: BERMUDEZ AZNAR, Agustín - El corregidor en Castilla..., op. cit., p. 70.

Medievalista online № 18| Julho - Dezembro 2015 ๑ IEM - Instituto de Estudos Medievais 16 www2.fcsh.unl.pt/iem/medievalista 
Función pacificadora y judicial de los corregidores en las villas y ciudades castellanas,

a fines de la edad media María Asenjo-González

las ciudades castellanas del periodo. En este sentido, la intervención regia aportaba una solución mediadora pero sin que ello supusiese hacer uso del regimiento al servicio de la “administración central”, concepto que superaba con creces las ambiciones políticas de la monarquía, a mediados del siglo XIV. Aunque sí podía sancionar con reconocimiento el nuevo reparto del poder en el seno del concejo, como resultado del acuerdo, tal y como ocurrió en Burgos, en 1345, o bien de la imposición de uno de los rivales en la lucha entre caballeros y hombres buenos, que necesitó de la presencia pacificadora del juez de salario, el mismo año, en Segovia.

En esta ciudad, el juez de fuera aparece ya mencionado en el privilegio de constitución de regimiento de $1345^{43}$. Su intervención se relaciona con las dificultades de entendimiento de la incipiente oligarquía. Esa rivalidad venía marcada por el enfrentamiento, que se documenta a fines del siglo XIII, entre las jerarquías naturales de los hombres buenos y los caballeros villanos, agrupados en dos linajes. Para éstos la instauración del regimiento supuso una victoria, ya que los dos linajes nombrarían a diez de los quince regidores del concejo ${ }^{44}$. Esa casi permanente presencia del juez de fuera se dotaba con un elevado salario de 8.000 mrs., que ya figuraba asignado y cabe suponer que se recurría a su intervención cuando se hiciese necesaria. Lo cual denota una permanencia del juez de salario en la ciudad, asociada a las secuelas de rivalidad y el conflicto ${ }^{45}$.

Bajo el enfoque institucional de oficio regio, se ha destacado que ese juez de fuera o de salario tenía las funciones de un juez concejil con competencias de supervisor ${ }^{46}$ pero

\footnotetext{
${ }^{43}$ REPRESA RODRÍGUEZ, Amando - Notas para el estudio de la ciudad de Segovia en los siglos XII$X I V$. Segovia: Instituto Diego de Colmenares, 1950, pp. 26-30, p. 30: Constitución del regimiento de Segovia otorgado por Alfonso XI (5 de mayo de 1345): "E pues que estos an de tener cuydado de los ofiçios del Conçejo que de aqui adelante non se ayunten nin se faga Concejo ni ayuntamiento ninguno en la dicha villa, salvo por nuestras cartas, quando estos sobredichos con el Jues de fuera o con los alcalles e el alguasil que y fueren, vieren que cumple de les faser ayuntamiento".

${ }^{44}$ ASENJO GONZÁLEZ, María - Segovia. La ciudad y su tierra a fines del medievo. Segovia: Diputación Provincial, 1986, pp. 436-453.

${ }^{45}$ GUGLIELMI, Nilda - "Los alcaldes reales en los concejos castellanos". in Anales de Historia antigua y medieval. 7 (1956), pp. 79-109. Sobre jueces de salario y de fuera esta autora asegura que ambos son de nombramiento real, no originarios de la ciudad o villa, anuales, remunerados por el concejo y auxiliados en su cometido por escribanos y ejecutores, pp. 86, 89 y 108.

${ }^{46}$ GUGLIELMI, Nilda - "La figura del juez en el concejo (León-Castilla siglos XI y XIII)”. in Melanges offerts á Rene Crozet. Poitiers: Société d’Études Médiévales, 1966, pp. 1003-1024, pp. 1010, 1022 y 1007 y BERMUDEZ AZNAR, Agustín - El corregidor en Castilla..., vol. 1, p. 77.
}

Medievalista online $N^{\circ} 18 \mid$ Julho - Dezembro 2015 ๑ IEM - Instituto de Estudos Medievais 17 www2.fcsh.unl.pt/iem/medievalista 
interesa poner de manifiesto que se trataba más que nada de un elemento mediador, en un marco de conflicto, que precisaba de la acción de arbitraje de un foráneo, de probada neutralidad. Esta función mediadora encajaría mejor con el carácter de un cargo de comisión que de oficio, transformación institucional que no se daría hasta el reinado de los Reyes Católicos ${ }^{47}$.

Se ha dicho que la difícil situación segoviana no fue equivalente a la de la ciudad de Burgos, que en el mismo año de 1345 recibió una carta plomada, con la que se regula la composición del concejo en regimiento ${ }^{48}$. El reparto de cargos recayó en dieciséis hombres buenos, que los recibirían de forma vitalicia, sin aludir a linajes ni a presencia de caballeros en la ciudad. Es posible que, tal y como se dice en el documento, la razón para disponer la reducción de los participantes en el concejo a dieciséis, se conectase con las frecuentes discordias que surgían en las reuniones, aunque las razones de conflictividad no fueron insalvables. Por ello, la solución de gobernar en concejo cerrado habría madurado entre los poderes concurrentes de esa ciudad, quedando sólo a la espera de la confirmación regia. Además, las disposiciones que se desarrollaron en el mismo documento dejaban constancia de que el asunto más polémico del debate interno habría sido el nombramiento de oficiales, ya que el documento se detiene en precisar la designación de mandaderos ${ }^{49}$. Pero la rivalidad por el nombramiento de oficios no quedó resuelta por mucho tiempo ya que en 1411 requeriría de un acuerdo complejo entre las collaciones de vecinos y los regidores, en la conocida sentencia del conde de Castro $^{50}$. El desarrollo político de Burgos se atuvo, por tanto, a las soluciones de

\footnotetext{
${ }^{47}$ El dilema de si se trata de oficio o comisión se resuelve desde el análisis de los documentos de nombramiento y no de la valoración de su presencia en el contexto de rivalidades y enfrentamientos que hacían necesaria su intervención. Ibidem, p. 78. Aunque aprecia en el corregidor un contrasentido, ya que actuando como comisionado se le consideraba un oficial, lo cual considera acorde con las inconcreciones previas a la institucionalización, p. 79.

${ }^{48}$ GONZALEZ DIEZ, Emilian - Colección diplomática del concejo de Burgos (884-1369). Burgos: Ayuntamiento de Burgos, 1984, pp. 360-367 y BONACHIA HERNANDO, J.A.: El concejo de Burgos en la Baja Edad Media (1345-1426). Valladolid: Universidad de Valladolid, 1978, doc. 5, pp. 151-154.

${ }^{49}$ Ibid., p. 152. "E que estos sobredichos ayan otrosy poder de dar e partir en cada anno los ofiçios, de la villa que el Conçeio e las vezindades de la dicha çibdat solíen dar e partir en cada anno entre sy en el tiempo que el Conçeio e las vezindades lo solían dar e partir, e que non aya y otros ofiçiales de los que el Conçeio e las collaçiones solían dar e poner en la dicha çibdat nin los doze nin los quatro nin los veynte e seys, saluo los que estos sobredichos ordenaran e dieren con los alcaldes ordinarios e merino e escriuano mayor".

${ }^{50}$ Ibid., doc. 13, pp. 164-168.
}

Medievalista online № 18| Julho - Dezembro 2015 ๑ IEM - Instituto de Estudos Medievais 18 www2.fcsh.unl.pt/iem/medievalista 
acuerdo de sus hombres buenos y sus rivalidades no requirieron la presencia del juez de salario ni del corregidor ${ }^{51}$.

Se confirma que el corregidor no parece haber sido pieza fundamental en la instauración del regimiento y tampoco su presencia se documenta en todas las ciudades que lo solicitaron. Por ello, sin quitar importancia a las reflexiones de Cerdá Ruiz Funes sobre la conflictividad en los concejos, a partir de los cambios asociados al crecimiento demográfico, el desinterés de los vecinos en la asistencia a las reuniones del concejo y los precedentes de buen funcionamiento del concejo cerrado en villas de Andalucía $^{52}$, cabe reconocer que fue la propia dinámica política de la sociedad urbana la que generó diferencias y disturbios, que enfrentaron a caballeros y hombres buenos y en las que arrastraban a sus clientelas. Pero, aunque el trasfondo de conflictividad tenía distintos niveles de acción, en los que cabían diferentes conflictos, en ningún caso las diferencias se tradujeron en pérdidas de autonomía de los concejos y de progresivo debilitamiento, como consecuencia de la presencia de corregidor. Esta interpretación, parece estar basada en una ingenua visión utópica y asamblearia de la vida concejil, que percibe el proceso de implantación del regimiento, en el siglo XIV, como un retroceso en el desarrollo político y social de las ciudades, cuyos vecinos habrían perdido derechos y competencias de gobierno con la intervención de la monarquía. Pero la sociedad del concejo abierto también estaba jerarquizada en clave de afinidades de parentela y dependencia, y en ella hombres buenos y caballeros se disputaban una primacía que, desde el siglo XII, se nutría de afines partidarios atraídos por nuevas formas de captación de índole clientelar o vasallático. Entre los hombres buenos se encontraban los mercaderes y artesanos enriquecidos, alejados del oficio de armas, que definía el perfil militar y social de los caballeros villanos.

51 La primera mención conocida de la presencia del corregidor en Burgos se remonta a 1400: BONACHIA HERNANDO, Juan Antonio - "Materiales para el estudio del régimen de corregidores (Burgos 1458-1465)”. in Cuadernos de Historia de España. 75 (1998-1999), pp. 135-159, p. 136.

52 CERDA RUIZ-FUNES, Joaquin - "Hombres buenos, jurados y regidores en los municipios castellanos de la Baja Edad Media”. in Actas del I Symposium de Historia de la Administración. Vol. 1. Madrid: Instituto de Estudios Administrativos, 1970, pp. 161-206.

Medievalista online № 18| Julho - Dezembro 2015 ๑ IEM - Instituto de Estudos Medievais 19 www2.fcsh.unl.pt/iem/medievalista 
Las escasas fuentes documentales sobre diferencias y rivalidades urbanas complican un seguimiento preciso del proceso pero, hechas las salvedades pertinentes, y si nos situamos en el marco urbano, los propios privilegios de concesión del regimiento son coherentes con el trasfondo de rivalidad social de su vida política, antes de la concesión del regimiento. Las disposiciones introducidas se supone que trataban de mejorar el desarrollo de la vida urbana, poniendo los medios que evitasen discordias, y el conocimiento de esos detalles también puede ayudar a entender la necesidad de la presencia del corregidor en el concejo en un cierto momento ${ }^{53}$.

\section{Otras interpretaciones: La función pacificadora del corregidor}

En este panorama de interés por la figura del corregidor, cabe preguntarse por su pertinencia y por su función en el marco de la vida política urbana, donde se testimonia su presencia por la necesidad y utilidad de su intervención, destacando su carácter de figura de paz en momentos de crisis. Por lo que cabe preguntarse si el recurso a la intervención del corregidor no representaría un síntoma de inoperatividad y de agotamiento político urbano, que dejaba constancia de los problemas de ingobernabilidad que vivieron las ciudades castellanas y que en muchos casos estaban relacionados con las competencias de la justicia. La complejidad de la sociedad oligárquica y las dificultades con que se afrontaban la solución de conflictos y debates en su seno requerían esa acción de los mediadores, ya que en estos conflictos tampoco ayudaba la legislación foral, que se mostraba incapaz ante sociedades que habían cambiado y se habían distanciado del modelo jerárquico y grupal del concejo abierto. La polarización y las afinidades de los agrupamientos clientelares, atizados por la presencia de la nobleza en las ciudades, exigían nuevas vías legales y tácticas de acuerdo, aunque en ocasiones se enquistaban en el enfrentamiento. La aparición de linajes de caballeros, que disputaban a las jerarquías de hombres buenos el poder, situaba el enfrentamiento en referentes de rivalidad dual. Esa dualidad resultaba menos operativa en las acciones

\footnotetext{
${ }^{53}$ Las crónicas son más elocuente acerca de la conexión entre presencia del corregidor y conflicto en la ciudad: ORTIZ DE ZUÑIGA, Diego - Anales eclesiásticos y seculares de la Muy Noble y Muy Leal ciudad de Sevilla. Vol. II. Madrid: en la Imprenta Real, 1795, p. 353.
}

Medievalista online № 18| Julho - Dezembro 2015 ๑ IEM - Instituto de Estudos Medievais 20 www2.fcsh.unl.pt/iem/medievalista 
de justicia, cuando no se alcanzaban acuerdos, o al quedar empañadas por la proximidad, el interés y el favor a alguna de las partes. Ante esa incapacidad del derecho foral y de las justicias locales para cerrar procesos y debates con sentencias ecuánimes y exentas de parcialidad, se abrían las opciones a la intervención de los tribunales del rey, recogidas en el Ordenamiento de Alcalá (1348), y también a la presencia mediadora de un pacificador para actuar en el ámbito urbano. Pero el intento de extensión del régimen de corregidores se atribuye a Enrique III $^{54}$, aunque posteriormente las cortes de Madrid de 1419 pidieron a Juan II que no enviase corregidores, salvo que la villa o ciudad con jurisdicción así lo solicitara. Ya en las Cortes de León de 1349 los procuradores solicitaron que los “jueces de salario” no debían ser enviados, salvo cuando lo pidiesen los concejos o la mayor parte de sus miembros. Pero a esta solicitud añadiría Alfonso XI “...o quando entendiéremos de lo poner que cumple a nuestro servicio”, con lo que se abrían las puertas a la atención de reclamaciones no institucionales dentro del propio concejo, siempre que los miembros del Consejo Real lo aprobasen. De ese modo, la monarquía atendería cualquier solicitud de parte suficiente para el envío de corregidor, con lo que se mermaban las opciones de reconducir internamente los conflictos en el seno de las ciudades y se favorecía la acción de la justicia regia ${ }^{55}$.

Desde la perspectiva local, el recurso a la intervención de un agente ajeno al marco establecido de resolución de conflictos vendría justificado por diferencias insalvables o por las limitaciones de los medios jurídicos al alcance ${ }^{56}$. Pero, ante determinados conflictos, los poderes afectados parecen servirse de técnicas de doble naturaleza, práctica e ideológica, y recurren a instrumentos normativos, políticos e institucionales

\footnotetext{
${ }^{54}$ Esto es lo que refiere el cronista Pedro LÓPEZ DE AYALA - “Crónica de don Enrique III...”. in Crónicas de los Reyes de Castilla. Vol. LXVIII. Madrid: BAE, 1779-1780, p. 247.

${ }^{55}$ BERMUDEZ AZNAR, Agustín - El corregidor en Castilla..., op. cit., p. 27. La interpretación asociada a las competencias de la monarquía complementa esta visión de interés local en mantener la nominación bajo control del poder urbano.

${ }^{56}$ En el curso del siglo XIV las disensiones en el seno del concejo entre hombres buenos y caballeros estuvieron en el seno del regimiento como modelo de gobierno y las rivalidades entre caballeros y escuderos surgieron en ciudades como Segovia en 1302, dando lugar a la asignación de quiñones en las tierras del sur de la Sierra de Guadarrama: ASENJO GONZALEZ, María - "Los Quiñoneros de Segovia (siglos XIV-XV)”. in En la España Medieval. 2 (1982), pp. 59-82.
} 
complejos $^{57}$. Esa elaborada trama de funcionamiento escapa muchas veces a su percepción, en el seguimiento de los procesos que requirieron la intervención del corregidor, pero conviene tenerla presente para comprender las argumentaciones y razonamientos de los concejos al rey sobre las funciones y competencias del corregidor, ya que para reconducir algunos de los conflictos planteados era preciso recurrir a una salida de acuerdo.

La acción mediadora del corregidor se basaba en su prestigio, condición social y origen a lo que añadía su autoridad personal, ya que muchos de los corregidores se elegían de entre los miembros de las élites urbanas y de la nobleza de menor rango. Todos estos aspectos quedaban reforzados con la “extranjería municipal” del elegido, que aseguraba su imparcialidad en el asunto tratado. Esas circunstancias realzaban su papel y validaban la solución mediadora de su intervención para poner fin a los conflictos y tensiones entre los grupos de poder municipal. En el reinado de Enrique IV se recurrió con frecuencia a la figura del gobernador, un oficio municipal que presentaba analogías con el corregidor, puesto que también había sido creado para mantener el orden público en las ciudades, cuando se encontrara alterado o en peligro. Por ello, se dotó de gobernadores a ciudades como Burgos, Toledo y Sevilla, en razón de la existencia de banderías locales que amenazaban el orden y la paz local; y también a villas como Jaén y Murcia, por su condición de ciudades fronterizas.

Por otra parte, la acción del corregidor en la ciudad no era fácil, a pesar de contar con oficiales, medios coercitivos y una capacidad resolutiva amparada por la corte de justicia y el Consejo Real. A su vez, el propio corregidor se vería controlado por la temporalidad de su cargo y la obligación de someterse al juicio de residencia, que evaluaría posibles irregularidades en el desarrollo de su oficio ${ }^{58}$. Así, su acción en la defensa de los intereses del común, tal y como se manifiesta en la segunda mitad del

\footnotetext{
${ }^{57}$ Lejos de concebir el funcionamiento concreto de determinados sistemas políticos sujetos a esquemas institucionales rígidos Massimo Vallerani invita a rexaminar los conflictos en el plano técnico de los instrumentos de poder y de gobierno en uso, sin atarlos a esquemas previos: "Introduzione". in VALLERANI, Massimo (ed.) - Tecniche di potere nel tardo medievo. Regimi comunali e signorie in Italia. Turín: Viella, 2010, pp. 7-24, p. 15.

${ }^{58}$ MONSALVO ANTON, José María - "El reclutamiento del personal político concejil. La designación de corregidores, alcaldes y alguaciles en un concejo del siglo XV". in Studia Historica. Historia. 5 (1987), pp. 173-195, p. 175.
}

Medievalista online № 18| Julho - Dezembro 2015 ๑ IEM - Instituto de Estudos Medievais 22 www2.fcsh.unl.pt/iem/medievalista 
siglo XV, aparece conectada con las garantías protectoras de la figura del corregidor en Segovia $^{59} \mathrm{y}$, en Logroño, el corregidor fue acusado de tomar decididamente partido por el estamento de los ciudadanos, en contra de los intereses de los otros dos estamentos en que se dividía la población laica de la ciudad, el de hidalgos y el de labradores ${ }^{60}$. En otras ocasiones era frecuente encontrar testimonios que acusaban al corregidor de tener alianzas con algún miembro de la oligarquía o regidores. En el período de las Comunidades los comuneros se opusieron a los corregidores y en los capítulos para la reforma del reino, que la Santa Junta trató sin éxito de hacer llegar al rey a Flandes, se propuso que en adelante no se proveyese de corregidores a las ciudades, a no ser que éstas solicitaran expresamente su envío. Como alternativa, los comuneros se limitaron a recomendar que las ciudades pusiesen alcaldes ordinarios "que sean suficientes”. No hay que olvidar que el pago del salario de los corregidores era muy gravoso para los concejos, por lo que podría ser impopular.

\section{La quiebra de la paz como asunto de competencia monárquica}

Los poderes municipales manejaban un extenso repertorio de medidas tendentes a garantizar la paz (“su” paz), que iban desde el sustento de la salud pública, la salvaguarda de la venta y el tráfico comercial y la mejora del sistema productivo, hasta la provisión de productos de primera necesidad y el desarrollo de la legislación contra la violencia. Contaban con ordenanzas para limitar el uso de las armas, había toques de queda al atardecer (que clausuraban las puertas de la urbe y prohibían la circulación excepto de forma excepcional, con luz y desarmados), regulaban el control de tabernas,

\footnotetext{
${ }^{59}$ Con frecuencia se alude a su presencia para dar valor legal a las reuniones del común: ASENJO GONZÁLEZ, María - "Ambición política y responsabilidad de gobierno. El "común" en Segovia y Valladolid a fines de la Edad Media". in OLIVA HERRER, Hipólito Rafael; CHALLET, Vincent; DUMOLYN, Jan; CARMONA RUIZ, María Antonia (ed.) - La comunidad medieval como esfera pública. Sevilla: Universidad de Sevilla, 2014, pp. 73-106.

${ }^{60}$ DIAGO HERNANDO, Máximo - "El papel de los corregidores..., op. cit., p. 206. En 1509, el capitán de la frontera de Navarra, Juan de Silva, fue apoyado por el estamento de los ciudadanos de Logroño que se movilizó para solicitar al rey una prórroga en el ejercicio del oficio de corregidor de esta ciudad para el bachiller Peñalver, provocando así una airada reacción de los otros dos estamentos, el de hidalgos y el de labradores, que denunciaban la mala gestión del bachiller Peñalver y solicitaban el envío de un juez de residencia.
}

Medievalista online № 18| Julho - Dezembro 2015 ๑ IEM - Instituto de Estudos Medievais 23 www2.fcsh.unl.pt/iem/medievalista 
mesones y prostíbulos, la fiscalización del juego, rondas nocturnas, la expulsión de vagabundos y proxenetas, limitaciones a la venganza y a la justicia privada, daban órdenes a los vecinos (para que estuviesen listos para actuar en caso de requerírseles su ayuda para perseguir a un delincuente), etc. Se trataba de medidas preventivas acompañadas de otras represivas como el encarcelamiento, la muerte por ejecución, las mutilaciones, las sanciones económicas o el perdón y el olvido -tan importantes a la hora de establecer una tregua o una paz firme ${ }^{61}$.

Desde el siglo XII, también se temía a los perturbadores de la paz por distintas causas entre las que se encontraban: los criminales, los ladrones, los que hacían falsa moneda, los traidores al señor, los asesinos, los que socorrían a un ladrón, los adúlteros e incestuosos $^{62}$. Romper la paz -fuese la establecida por un tratado o la que debía mantenerse por respeto a las fuerzas estatales- significaba una triple ofensa: individual (contra la víctima directa de la acción); social (contra la comunidad en su conjunto); y política (contra la autoridad que representaba, defendía y había instaurado la paz conculcada) ${ }^{63}$. La paz, en todo caso, tenía muchos enemigos y los elementos que la ponían en jaque eran: la guerra, las luchas de bandos, los conflictos entre omes poderosos, la tensión oligarquía-común, los alzamientos de bienes, los críticas de las aldeas, las rivalidades entre poderes colindantes y la resistencia antiseñorial ${ }^{64}$.

Pero pronto la quiebra de la paz en el reino pasó a ser competencia regia y se tomaronn precauciones en momentos especiales y espacios simbólicos ${ }^{65}$. Los perturbadores de la paz era personas conocidas o anónimas, que participaban en desórdenes y escándalos, y aparecen en denuncias ante los oficiales regios y demandas al corregidor, como

${ }^{61}$ CÓRDOBA DE LA LLAVE, Ricardo - "Violencia cotidiana en Castilla a fines de la Edad Media”. in IGLESIA DUARTE, José Ignacio de la (ed.) - Conflictos sociales, políticos e intelectuales en la España de los siglos XIV y XV. XIV Semana de Estudios Medievales, Nájera, del 4 al 8 de agosto de 2003. Logroño: Instituto de Estudios Riojanos, 2004. pp. 393-443, en concreto pp. 428-432.

${ }^{62}$ LAMBERT, T. B. - "Theft, Homicide and Crime in Late Anglo-Saxon Law”. in Past and Present. 214 (february 2012), pp. 3-43, en concreto p. 40.

${ }^{63}$ GUERRERO NAVARRETE, Yolanda - "Orden público y corregidor en Burgos (siglo XV)". in Anales de la Universidad de Alicante. Historia Medieval. 13 (2000-2002), pp. 39-102, en concreto pp. 63-64.

${ }^{64}$ VAL VALDIVIESO, María Isabel del - "La perturbación de la paz urbana en la Castilla del siglo XV". in La convivencia en las ciudades medievales. Encuentros internacionales del Medievo 2007, Nájera, del 24 al 27 de julio de 2007. Logroño: Instituto de Estudios Riojanos, 2008, pp. 23-51.

65 LÓPEZ GÓMEZ, Óscar - "Pas e sosiego. Un argumento de acción política en la Castilla bajomedieval”. in Medievalismo. Boletín de la Socciedad Española de Estudios Medievales. 16 (2006), pp. 41-71.

Medievalista online № 18| Julho - Dezembro 2015 ๑ IEM - Instituto de Estudos Medievais 24 
burladores de la justicia que generaban inseguridad ciudadana. Ciertamente, sus acciones eran vistas como una amenaza para la paz y el orden, y solía culpárseles de estar detrás de ruidos, conspiraciones y asambleas ilícitas peligrosas para el status $q u o^{66}$.

La acción del corregidor se entendía favorable al restablecimiento de la paz, pero si realizaba un alineamiento político su acción mediadora se desvanecía y era acusado de tener afinidades y realizar acciones partidistas. Ciertamente, la prolongada presencia en una misma ciudad se prestaba a esas connivencias tal y como ocurrió en Soria con el corregidor Vazquez de Cuéllar, ya que él y su padre lo fueron desde tiempos de la reina Isabel hasta 1517, lo cual desató el descontento en la ciudad ${ }^{67}$. Aunque lo cierto es que con bastante frecuencia los corregidores no supieron actuar como poderes moderadores, capaces de imponer soluciones conciliatorias a las facciones enfrentadas en cada ciudad, sino que, por el contrario, actuaban con parcialidad y se granjeaban la enemistad de los que se sentían perjudicados por su irregular comportamiento.

Pero los corregidores fueron también victimas de los cambios políticos en la corte y de las alteraciones políticas del reino que afectaron a su seguridad y solvencia. Así, entre 1506 y 1507, a la muerte de Felipe de Hagsburgo, que había renovado a los corregidores en muchas ciudades destituyendo a los nombrados por el rey Fernando, se procedió a su destitución y muchos de los nombrados se negaron a dejar sus cargos. Por entonces, Cuenca, Segovia, Oviedo, Córdoba y Toledo vivieron episodios de violencia y de abierta rebelión por las innovaciones impuestas a la muerte del rey Felipe ${ }^{68}$.

El gran cambio en la figura del corregidor fue consecuencia de las capítulos aprobados en las Cortes de Toledo de 1480, que contribuyeron a crear conciencia de que la nueva monarquía tenía un programa de gobierno y había logrado por su voluntad romper una

\footnotetext{
${ }^{66}$ COHN, Samuel K (Jr.) - Lust for Liberty: The Politics of Social Revolt in Medieval Europe, 12001425. Cambridge: Harvard University Press, 2006, p. 4.

${ }^{67}$ DIAGO HERNANDO, Máximo - “El papel de los corregidores,,,”, op. cit., p. 206.

${ }^{68}$ ASENJO GONZALEZ, María - "Ciudades y oligarquía urbana en Castilla en los años de la "Gobernación" de Fernando el Católico (1506-1516)". in ANATRA, Bruno; MURGIA, Giovanni (ed.) Sardegna, Spagna e Mediterraneo. Dai Re Cattolici al Secolo d'Oro. Roma: Carocci Editore, 2004, pp. 125-142.
}

Medievalista online № 18| Julho - Dezembro 2015 ๑ IEM - Instituto de Estudos Medievais 25 www2.fcsh.unl.pt/iem/medievalista 
Función pacificadora y judicial de los corregidores en las villas y ciudades castellanas,

a fines de la edad media María Asenjo-González

actuación política anterior presidida por él desorden, la inseguridad y la justicia ${ }^{69}$. Se dieron importantes funciones judiciales a los corregidores y éstos pasaron a ocupar un lugar tan destacado que algunos autores hablan de jueces-corregidores, y de esta forma llegaron a convertirse en el órgano normal de la jurisdicción local ordinaria, fijando el ordenamiento de Cortes algunas competencias de su funcionamiento. Antes de 1480, y en el contexto de la guerra civil, los reyes intervienen directamente en los conflictos de las ciudades, aprovechado esa ventaja para sustituir regidores no afines a su causa y eliminar enemigos ${ }^{70}$. Aunque lo cierto es que el envío de corregidores se convirtió en un arma política de primer orden para los Reyes Católicos que les aseguraba contar con un agente privilegiado para cualquier gestión o acción regia $^{71}$. Además, su número creció y en 1494 había 54 corregimientos, en 1515 había 61. En 1575 habría 63 y 68 en 1597. El oficio se difundiría y se regularizaría hasta institucionalizar su presencia en las poblaciones urbanas más características ${ }^{72}$.

\section{Conclusión}

A fines de la edad media el corregidor se había hecho necesario a las funciones del gobierno regio porque actuaba sobre dos referentes fundamentales: la justicia y la paz y también asumía competencias de supervisión en fiscalidad y organización militar. Todas esas responsabilidades estaban relacionadas con los intereses de la monarquía en las ciudades de destino y le proporcionaban gran influencia en la vida municipal, concurriendo con las opciones de gobierno emanadas del regimiento. En el análisis

\footnotetext{
${ }^{69}$ Sobre el concepto de "bien común”: BLICKLE, Peter - "El pricipio del "bien común"como norma para la actividad política. (La aportación de campesinos y burgueses al desarrollo del Estado Moderno temprano en Europa Central)". in Edad Media. Revista de Historia. 1 (1998), pp. 29-46. BONACHIA HERNANDO, Juan Antonio - "La justicia en los municipios castellanos medievales". in Edad Media. Revista de Historia Medieval. 1 (1998), pp. 145-182. Opina que un buen gobierno es un gobierno justo, unido al bien común. Ver: NIETO SORIA, José Manuel - Fundamentos ideológicos del poder real en Castilla (siglos XIII-XVI). Madrid, Universidad Complutense Eudema, 1988, pp. 146-151.

${ }^{70}$ LUNENFELD, Marvin - Los corregidores de Isabel la Católica. Barcelona: Labor, 1989, pp. 41-45.

${ }^{71}$ FORTEA PÉREZ, José Ignacio - "Los Corregidores de Castilla bajo los Austrias: Elementos para el Estudio Prosopográfico de un Grupo de Poder (1588-1633)”. in Studia historica. Historia moderna. 34 (Ejemplar dedicado a: Perspectivas del mundo urbano (siglos XV-XVII)), 2012, pp. 97-144.

${ }^{72}$ GONZÁLEZ ALONSO, Benjamín - "Monarquía, ciudades, corregidores (Castilla, 1480-1523)”. in BELENGUER CEBRIÀ, Ernest (ed.) - De la unión de coronas al Imperio de Carlos V. Vol. I. Madrid: Sociedad estatal de la conmemoración de los centenarios de Felipe II y Carlos V, 2001, pp. 281-298, p. 285.
}

Medievalista online № 18| Julho - Dezembro 2015 ๑ IEM - Instituto de Estudos Medievais 26 www2.fcsh.unl.pt/iem/medievalista 
propuesto se ha hecho hincapié en estudiar la figura del corregidor desde la óptica del interés urbano y de la aportación de su intervención a la pacificación y a la prolongación de la vida política concejil, bajo el modelo oligárquico de gobierno. La solidez de sus actuaciones conectaba con la creciente convicción social de lograr amparo en una justicia desligada de los poderes locales y de la inconveniencia de prolongar conflictos que amenazasen la paz. Así, justicia y paz surgirían como valores modernos que conectaban abiertamente con los propósitos de gobierno del poder regio desde fines de la edad media.

Si en el siglo XIV y hasta mediados del XV la función pacificadora había sido fundamental para la existencia del corregidor. El papel de mediador en los conflictos le otorgaba garantías de aceptación, a las que se añadía la condición de enviado regio, pero la aceptación de su presencia no siempre contó con la aquiescencia de todos los implicados. De ahí que se produjesen rechazos y oposición, en el seno de las comunidades en las que el corregidor intervenía. El cambio en su función y competencias llegaría en 1480, cuando se normalizaba su acción, en el marco de defensa de los intereses de la monarquía en la ciudad, que se les aseguraba permanencia prolongada y también difusión por las villas y ciudades del reino, al margen de que hubiese solicitud previa. Se podría asegurar que tanto el oficio como sus funciones fueron transformados a partir de entonces y sus acciones pasaron a ser claves, tanto en el seno de los concejos como en el marco de la gestión y gobierno del reino, realizada a instancias de la acción regia. Algunos de los corregidores fueron “continos” reales y hombres de confianza de la Corte, que a su vez eran regidores u hombres de armas, y entre ellos se perfilaba con nitidez el predominio creciente de los hombres de leyes, formados en las universidades del reino y conocedores del derecho común. Pero la importancia de su función parece creciente, en un contexto político con nuevos actores que demandaban participación política, tal y como manifestaban las acciones del común o la comunidad, colectivo urbano muy activo a fines del siglo XV. La permanencia y creciente demanda, desde las ciudades, de intervenciones del corregidor en los asuntos urbanos contribuye a la generalización de los nombramientos y a la oficialidad del cargo que, a partir de 1480, incrementó sus competencias.

Queda probada la pertinencia de un enfoque nuevo de estudio de la figura del corregidor desde las lógicas de comportamiento social de la oligarquía urbana, que se mantuvieron 
activas en todo momento y que incluso llegaron a condicionar su cometido y acción institucional. En su consideración de emisarios regios, los corregidores del siglo XV todavía exhiben una vinculación vasallática directa con la monarquía. De su comportamiento y actividad hay aspectos que todavía resultan mal conocidos, como la concurrencia con las instancias judiciales locales, el beneficio que aportaba su extracción social sobre la formación jurídica que otros exhibían y que fue clave en la difusión y aplicación del “derecho común” en los asuntos de su intervención. También habría que determinar la perduración de los corregidores y asistentes en sus cargos, con la posibilidad de conocer sus trayectorias y el cursus honorum que les definía y al que se plegaban en su promoción.

\section{Referência electrónica:}

ASENJO-GONZÁLEZ, María - "Función pacificadora y judicial de losi corregidores en las villas y ciudades castellanas, a fines de la edad media”.

Medievalista [Em linha]. № 18 (Julho - Dezembro 2015). [Consultado dd.mm.aaaa].

Disponível em

http://www2.fcsh.unl.pt/iem/medievalista/MEDIEVALISTA18/gonzale.z1804.html ISSN 1646-740X.

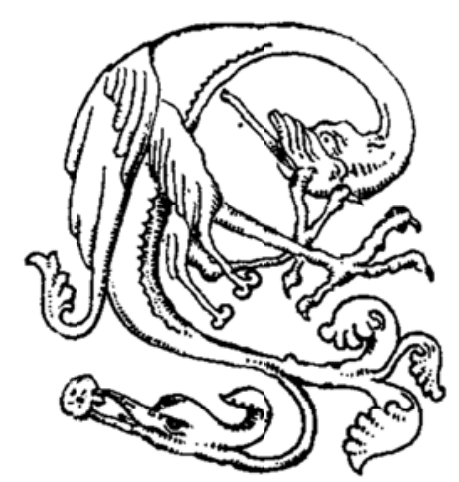

Medievalista online № 18| Julho - Dezembro 2015 ๑ IEM - Instituto de Estudos Medievais 28 www2.fcsh.unl.pt/iem/medievalista 